\title{
MILITARY EDUCATION AND TRAINING SUPPORTED BY BLENDED SIMULATION
}

\author{
Pavel BUČKA, Vladimír ANDRASSY \\ Armed Forces Academy of General Milan Rastislav Stefanik, Liptovský Mikuláš, \\ Slovakia \\ pavel.bucka@aos.sk, vladimir.andrassy@aos.sk
}

\begin{abstract}
The existing conflicts, both military and non-military are currently mostly of non-linear nature, where units composed of multiple specializations, both smaller and acting independently are prevailing. Those units are usually separated from home base and proper access to its own central supply lines of communication which strengthens emphasizes on their independent command and control, coordination within deployed forces and other assets within given operation. Therefore, prior collective training and preparation for deployment is one of the crucial operational planning requirements before deployment takes place. Modern training simulation techniques and assets do support preparedness of those units planned for deployment by aligning and synchronizing interoperability of their activities. One of such techniques - Blended simulation - can realistically generate a wide range of situations with exact imitation of activities to practice the ability of different types of units to the declared capabilities across the broad spectrum of tasks. Evaluation of the blended simulation effectiveness does further help to deliver more efficient methodologies and tactical procedures for further use within preparation stag. Such approach is in line with the trend of increased use of modelling and simulation techniques within military education and training.
\end{abstract}

Keywords: military education and training, simulation tools, blended simulation, constructive simulation, virtual and live simulation.

\section{Introduction}

Current process of professional soldiers and crisis managers' preparation for dealing with likely risks, puts main emphasis on decision making processes - processes built on command and control. These processes are described as a result of conscious decision making of individuals, commanders and crisis staff personnel in given operation environment, timeframe and within specific conditions, like for example decisions about employment of manpower and equipment in operations, or as a part of removal of consequences of natural disasters, terrorist attacks and unpredictable emergencies [6]. Progress of science, information technologies but also educational advancements does allow to qualitatively improve processes of education and training of security community, improve effectiveness of their preparation and adjust coordination of competent staff members for solution of complex crisis situations. An important element in this structure is human factor as commanding, execution and control subject. Preparation of this element for solving diverse non-standard situations in specific conditions is crucial.

The primary component of success is carefully designed and consistently implemented preventive measures. The intention is to prevent the commutation of all such funds, which would allow the emergence of aggressive activities. The essence is the shift in philosophy from 
training to combat threats to prevent these threats from their inception. [4]

It seems apparent, that computer simulation is one of the tools enabling effective preparation of individuals and staff members, their coordination and does provide environment for testing responsibilities for conflict resolution within specific scenarios. Simulation technologies are one of possible means to achieve desired and acceptable result of preparation for solving questions related to securing defense and protection.

\section{Blended simulation}

Simulation technologies do support in education system of security communities the effectiveness of staff members' preparation for anticipated events, which could occur during real employment of forces. The cornerstone for simulation of crisis situations is process of specification, implementation and execution of evolving crisis, supported by developed models, which are simulating required level of likely real situation. Verification of crisis scenario validity is possible to execute through blended simulation by simulating interrelations between constructive, virtual and direct simulation.

Constructive simulation is based on mathematical methods and broad use of modern computational and information technology. Its core principle is based on simplified representation of a real system by its simulated model, which behaves according to prior defined algorithms, entry parameters and given norms and rules. Model developed under such conditions fully represents real system with its measured values. It is set inside a synthetic virtual environment incorporating real maps and real technical parameters of equipment including distance ranges of specified units.

Virtual simulation does provide environment for tactical exercises of individuals as well as whole units. Training is focused on development of tactical and communication capabilities in command and control areas, acquiring, providing and transmission of information. It provides support for solving tasks related to psychological preparation, behavior in stressful situations and the need for decision-making under time pressure. Virtual reconfigurable simulator can represent diverse types of land and aerial equipment including equipment of integrated rescue system. It can be used for individual - separate training, but also as a means of wargaming of command exercise within computer assisted exercise (CAX).

Direct simulation supports cognition of reality through visual, auditory and tactile senses by using "real" technical equipment complemented by special ones.

The aim of blended simulation is to logically synchronize consequential events throughout planning and execution of both military and non-military activities, improve tactics and check on activities execution during deployment. By using blended simulation, it is possible to realistically simulate broad spectrum of crisis situations with realistic imitation of activities of participating units, train their abilities to solve related supporting or anticipated activities within the whole specter of assigned tasks.

Today in postmodern wars, the combat (not only) military activities taking place in the civilian population environment mostly. And experts begin to talk about the war in the social environment, in the urban areas and other sites. Actors of postmodern war are using guerilla methods and irregular forms of warfighting in heavily accessible terrain for modern forces which eliminates technological advantages and create new type of crisis situations [5].

Required outcome of blended simulation is realization of CAX based on interoperability of described types of simulation, so that it would be possible to:

a) Quantify events and processes which do optimize decision making of individuals and staff members on tactical level of command and control, for example by realization of war game with the element of 
securing management of subjective factors of mutual interactions within decision making processes,

b) Model situation occurring in any geographical region, within specified environmental and climatic conditions, throughout any initial gaming setup and used equipment based on existing or experimental standard operational procedures.

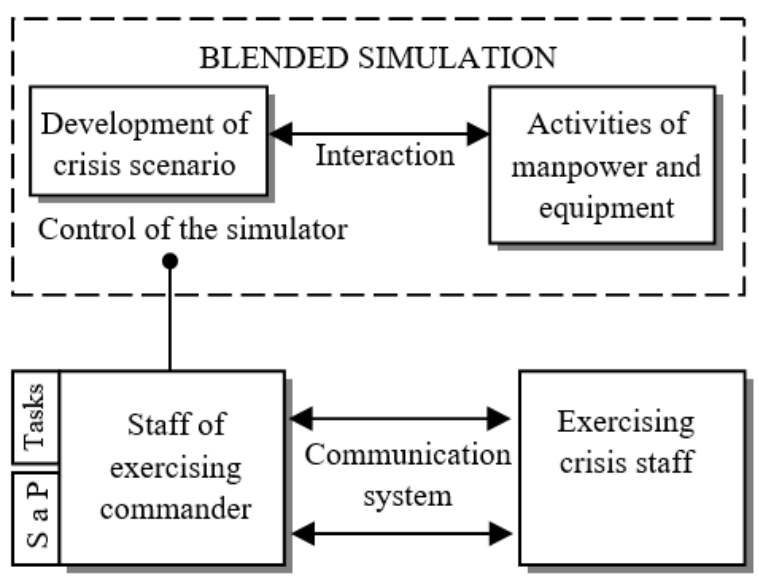

Figure 1: Simplified principle of crisis situation simulation Source: Own

\section{Crisis scenarios}

Training while exploiting simulation technologies does allow commanders and staff members to develop their decision making thought processes in both tactical and operational use of provided units and equipment. It provides realistic perspective on time and space factors during crisis situation, and deepens habits of exercising staff members, their interoperability during fulfillment of tasks, synchronization of tasks execution and their interrelation during organization and execution of operations within deployment environment. It strengthens the capacity to improve integration of support units while maximizing the utilization of existing units and equipment. It develops habits of proper use of terrain and environment. It increases the ratio of individuals or crisis managers respectively who do take part within command and control decision making processes of deployed units. The simulator allows a flexible and intensive training while providing variability by enabling changes for specific approaches in relation to decisions of exercising staff based on modeled scenario of crisis situation solution as provided in prepared exercise scenario.

Described process does have its consequential line of activities, used forms and methods which are dynamically interrelated to each other's goals, content, forms, methods, material and technical equipment. The result of this process can be termed as crisis scenario and can be simply characterized through following steps [1]:

a) Formulation of specific goals of the process, its clarification, specification and approval,

b) Selection of optimal methods, organizational forms and material equipment,

c) Actualization of procedures related to executional activities,

d) Modeling of situation in the way so that it forms coherent and logical unit,

e) Adoption of new factors,

f) Strengthening and deepening of acquired knowledge,

g) Control of results from the executed process.

Crisis scenarios are the result of crisis evaluation and eventual future security environment [7]. They contain description of causes influencing formation and continuance of crisis, description of possible impacts on lives, environment and society, but also they do clarify reactions and necessary measures of individual elements of crisis management system for creation and increase of threats [3]. Preparation of security communities by using supporting simulation tools will improve analysis and uniqueness of problems under consideration, and sketch interrelated variables and describe overall situation and likely implications. While solving crisis situation it is necessary to understand its underpinnings and have answer for question: "What will happen if...", and concurrently be conscious of related risks and localities. Programmed 
crisis scenarios will provide information with an emphasis on the feasibility of implemented wills, method of command and control and managing staff of forces and means. Software and hardware support tools of constructive, virtual and real simulation are helping to verify proposed procedures for solution of crisis situation while evaluating the likelihood of proposed initial hypothesis. Simulation will point on required specific tasks in relation to content and required end state of crisis event. After simulation execution and based on results of information gathering linked to exercises, it will define which activities of exercising units will be a part of analysis and to which extend they will be presented and implemented in future situations. Blended simulation will secure unified system of preparation for security community, ability to permanently train and acquire habits and their periodical renewal, unification of operational procedures while maintaining variability for possible solutions of specific stochastic or non-standard situations. It is possible with the support of simulation methods to explore complex systems by using compression or expansion of time factor. Simulation does support realization of controlled experiments and does help to understand functionality and consequentiality of separate steps of crisis scenario. Blended simulation does have advantages primarily in:

a) Improvement of decision making process of individuals and staff members during realization of protection, solution of crisis situation and during preparation, planning, realization or command of diverse types of operations,

b) Reviewing prepared operational plans, crisis plans and their interrelation in order to answer question about how realistically they reflect real conditions, while testing how those plans can be used with the focus on consequentiality and complexity of executed activities and their mutual synchronization, c) Standardization of qualitative and quantitative parameters,

d) Support for analytically unsolvable tasks, while uncovering complex interrelations and reactions on different stimulus and conditions,

e) Acquiring alternative solutions, helping to specify novel approaches leading to solution of crisis situations while saving environmental costs, costs for personnel, preparation and execution of live exercises while reducing overall risks related to live exercises.

Comparative cost analysis of real exercises in the field, with simulation exercises is 1 to 12 in favor of simulation exercises for mechanized units and 1 to 6 for supporting units. Despite of this fact it is important to bear in mind that real life exercises still do matter.

\section{Conclusions}

Simulation technologies do represent significant trend in training and education of units or crisis staff members and they enable preparation and development of capabilities and behavioral features of individuals as well as whole units to more effectively execute military and nonmilitary operations. Based on EU directive $2008 / 114 /$ ES from $8^{\text {th }}$ of December 2008 "About identification and designation of European critical infrastructures and assessment of the need to improve their protection" it is necessary to reevaluate approaches to such infrastructure [2]. It is required to develop normative, legislative and institutional tools for the analysis of weak points and consequent risks from both external as well as internal threats to critical infrastructure, definition of main permanent security regulations for its more effective protection. Blended simulation does improve effectiveness also in this area, mainly through preparation of security community for events, which would be otherwise very expensive to model for in real life conditions. It does support creation of real like conditions for simulation 
purposes generating modeled crisis situations with the consequent simulation of crisis development while providing information required for search of potential solutions. Simulation will provide balanced approach of defining driving features of situation under scrutiny and will provide environment for decision making of competent crisis managers, individuals and crisis staff members. It also will help within verification processes of specified crisis plans, application of those crisis plan processes and will create environment for testing effects and consequences of decisions made, while experimenting with created simulation models of real situation with the aim to acquire relevant base for optimization of activities in search for and consequent realization of proposed solutions.

\section{Acknowledgements}

This article was supported by the outcome of the project "Analysis and Simulation of Information and Security Threats Workplace (PASIBO)“, code OPVaV2015/1.1/03-SORO, ITMS code 26210120044.

\section{References}

[1] Andrassy, V., Grega, M.: Didaktické postupy riešenia úloh voblasti krízového manažmentu. Liptovský Mikuláš, Akadémia ozbrojených síl generála M. R. Štefánika, 2013. ISBN 978-80-8040-484-0.

[2] Andrassy, V., Jasenovec, J.: Využitie simulačných technológií v ochrane prvkov kritickej infraštruktúry. 14. medzinárodná vedecká konferencia, Fakulta špeciálneho inžinierstva Žilinskej univerzity, Žilina, 2009. ISBN 978-80-554-0014-3.

[3] Blažek, V., et al.: Krízové scenáre. Bratislava, Akadémia Policajného zboru v Bratislave, 2012. ISBN 978-80-8054-538-3.

[4] Majchút, I.: Armed forces as a tool for co-operation. Nieuchronna polisemia, potencjalna synergia: międzynarodowe, narodowe i lokalne aspekty bezpieczeństwa w Polsce i Słowacji, Ostrowiec Św. Stowarzyszenie Nauka Edukacja Rozwój, 2012. ISBN 978-8389466-46-4.

[5] Pikner, I.; Galatík, V.: The Use Of The Armed Forces In The Postmodern Wars. In: The 21th International Scientific Conference Knowledge-Based Organization. Management and Military Sciences. Sibiu, Romania: "Nicolae Balcescu" Land Force Academy Publishing House, 2015, p. 90-93. ISSN 1843-6722

[6] Spilý, P., Hrnčiar, M.: Vojenská taktika. Liptovský Mikuláš, Akadémia ozbrojených síl generála Milana Rastislava Štefánika, 2013. ISBN 978-80-8040-471-0.

[7] Kazanský, R., Melková, M.: Information technologies and their usage in crisis management as a tool to increase the quality of educational process. 15th international multidisciplinary scientific geoconference SGEM 2015, 18-24 June 2015, Albena Bulgaria : Ecology, economics, education and legislation : conference proceedings. Vol. III, Environmental economics, education and accreditation in geosciences. - 1. vyd. Sofia: STEF92, 2015. ISBN 978-619-7105-41-4. - ISSN 1314-2704. - S. 917-924. 